\title{
Optimization of Micro-Electrical Discharge Machining Parameters of Ti6AL4V Component: A Mapping Study
}

\author{
Christina Apostolopoulou ${ }^{1}$ \& Laith Abdullah Al-Juboori ${ }^{2}$ \\ ${ }^{1}$ Self Employed Researcher in Mathematics and Statistics, Athens, Greece \\ ${ }^{2}$ Eng. Technology \& Science Division (Mechanical Eng.), Higher Colleges of Technology, Fujairah, UAE \\ Correspondence: Christina Apostolopoulou, Self Employed Researcher in Mathematics and Statistics, Athens, Greece. \\ E-mail: apostolopoulou.stats@gmail.com
}

Received: November 4, 2019 Accepted: Decmeber 4, 2019 Online Published: December 16, 2019

doi:10.5539/jmr.v12n1p22

URL: https://doi.org/10.5539/jmr.v12n1p22

\begin{abstract}
The micro-Electrical Discharge Machining (micro-EDM) is a non-conventional machining process which utilizes electro-thermal, non-contact effects to remove material from the workpiece. Micro-EDM is controlled by many machining parameters and its accuracy is evaluated by performance measures. It is employed when high accuracy and precision are required, especially when difficult-to-machine materials, like titanium alloy $\mathrm{Ti}_{6} \mathrm{Al}_{4} \mathrm{~V}$, are involved. Given the tremendous applications of $\mathrm{Ti}_{6} \mathrm{Al}_{4} \mathrm{~V}$ in biomedical devices, automotive, aerospace and microelectromechanical systems, it is valuable to examine thoroughly the micro-EDM of $\mathrm{Ti}_{6} \mathrm{Al}_{4} \mathrm{~V}$ component. This work reports a systematic mapping study of 36 papers published in journals and proceedings of conferences in the nearly two decades 2000-2018. First, we divide the papers into categories according to the various optimization techniques applied for the enhancement of micro-EDM machining process of $\mathrm{Ti}_{6} \mathrm{Al}_{4} \mathrm{~V}$ component. Then, we discuss the techniques most used and give insight into the current research trends in micro-EDM. Accompanying comments about the use of the mentioned studies for teaching purposes may be of considerable interest for educators.
\end{abstract}

Keywords: grey relational analysis, micro-EDM, multilinear regression, performance measures, $\mathrm{Ti}_{6} \mathrm{Al}_{4} \mathrm{~V}$ alloy, Taguchi technique

\section{Introduction}

Titanium alloy $\left(\mathrm{Ti}_{6} \mathrm{Al}_{4} \mathrm{~V}\right)$ is one of difficult to machine materials mostly used in automobile, aerospace and medicine applications because of its low specific density and high specific strength properties and excellent corrosion resistance, lightweight and mechanical properties. However, the machinability of titanium alloys is regarded to be rather imperfect owing to properties of poor thermal conductivity, chemically reactivity and low elastic modulus. The conventional machining methods are unable to provide good machining and reliability characteristics and to satisfy surface integrity requirements (Ezugwu \& Wang, 2004).

Micro-Electrical Discharge Machining (micro-EDM) is one of the beneficial fabrication methods for creating complex geometries. The method is an electro-thermal process that removes the material by a series of electrical discharges with the aid of dielectric flushing that removes the debris from the sparking zone (Masuzawan, 2001).

Several works refer to experimental researches achieved to examine micro-EDM process. There are many factors affecting the micro-EDM process performance; these factors can be connected either to the process variables (like voltage, pulse duration, peak current, spark gap, feed rate, electrode rotation speed, flushing conditions) or to the system variables (like type of dielectric fluid, tool properties, chemical and physical material properties).

The machining performance (defined in terms of material removal rate MRR, electrode/tool wear rate EWR, overcut, diameter variance at entry and exit, machining surface integrity and accuracy) is influenced by the variables used (Weule et al., 2004).

The aim of this work is to collect and discuss the optimization techniques employed for detecting the optimal micro-EDM process parameters settings for a set of desired performances in micro EDM mechanical process of $\mathrm{Ti}_{6} \mathrm{Al}_{4} \mathrm{~V}$ alloy, and find the most influencing process parameters through reviewing the available research works from 2000 to the end of 2018. 


\section{Method}

\subsection{Research Questions}

This study addresses the following research questions:

- What are the optimization techniques of the micro-EDM process variables of $\mathrm{Ti}_{6} \mathrm{Al}_{4} \mathrm{~V}$ alloy presented in literature in the period 2000-2018?

- What are the quality parameters mostly targeted- and improved- in the optimization?

- To what extent have the optimization techniques been evaluated?

\subsection{Search Process}

In Mapping Studies and Systematic Literature Reviews, the search process is a critical part of the study since most of the relevant articles, ideally all, must be found and recorded.

It is recommended to use an automated keyword search of some well-known databases and snowballing (Kitchenham et al., 2009).

However, in this study, we decided to avoid search of databases because of the particularity of the subject: Researchers often are concerned with the universal intrinsic properties of the machining process and they do not mention the workpiece used in their article title, e.g., "The use of SiC powder in water as dielectric for micro-slit EDM machining" (Chow, Yang, Lin, \& Chen, 2008); sometimes they refer to the mechanical process as EDM, which is the conventional one and irrelevant to our study, with an adjective used later in the title that highlights its micro-scale nature, e.g., "Multi-Criteria Optimization of Electro-Discharge Micro-Hole Machining of $\mathrm{Ti}_{6} \mathrm{Al}_{4} \mathrm{~V}$ Super Alloy" (Kibria \& Pradhan, 2012); in many papers although optimal settings of input variables are found, the authors focus more on their newly developed or modified micro-EDM techniques and they don't mention the term "optimization", e.g., "Grey Relational Analysis of Micro-EDM Machining of $\mathrm{Ti}_{6} \mathrm{Al}_{4} \mathrm{~V}$ Alloy" (Meena \& Azad, 2012).

Obviously, search strings cannot find the above-mentioned articles, although they all refer to the optimization of micro-EDM of $\mathrm{Ti}_{6} \mathrm{Al}_{4} \mathrm{~V}$ alloy and are important to our study.

In this study, we used backward snowballing, identifying articles from the reference lists of some relevant articles, and afterwards, we applied forward snowballing identifying articles that have cited the articles we have already found. We confidently used the snowballing approach since it has been proved (Badampudi, Wohlin, \& Petersen, 2015) that key word search of databases and snowballing give conclusions and patterns quite similar. At the very end, having a robust knowledge about many of the studies, we investigated the Google Scholars database. The search covered the period from 2000 to 2018.

\subsection{Criteria}

We considered all papers describing the optimization of process variables of any of the four types of micro-EDM of $\mathrm{Ti}_{6} \mathrm{Al}_{4} \mathrm{~V}$. Optimization technique is any technique characterized as such in statistics or logic: Analysis of variance ANOVA, multiple regression, Grey relational analysis, Taguchi methods, fuzzy logic, neural network models, genetic algorithms, simulated annealing and any combination of any of these together.

We included all papers written in English, published in a journal or international conference proceedings which give one or more optimal sets of micro-EDM for $\mathrm{Ti}_{6} \mathrm{Al}_{4} \mathrm{~V}$ process parameters, for any combination of electrode used (related to their fabrication, geometry, shape or material), dielectric fluid, pulse generator and assistance in the machining process. We excluded single abstracts, papers in which the workpiece is not clearly mentioned, and literature reviews.

From each paper we extracted:

- Abstract and bibliographic information

- Date of the publication

- Country(ies) of the institution(s) of the authors

- Characteristics of micro-EDM process of $\mathrm{Ti}_{6} \mathrm{Al}_{4} \mathrm{~V}$ alloy like type, dielectric fluid, electrode material, process variables, and quality variables.

- Optimization technique

\section{Results}

\subsection{Search Results}

In this section, we present the results acquired after studying all the papers that were included as directly related to the optimization of process parameters of micro-EDM of $\mathrm{Ti}_{6} \mathrm{Al}_{4} \mathrm{~V}$ alloy. However, we seriously take into consideration four papers ( Kibria, Sarkar, Pradhan, \& Bhattacharyya, 2010; Kibria, Pradhan, \& Bhattacharyya, 2012; Tiwary, Pradhan, \& 
Bhattacharyya, 2014; Wang, Zhang, Liu, \& Huang, 2017) that did not meet the inclusion criteria, but accurately and laboriously describe the advantages of some dielectric fluids over others or the role of the geometry and shape of the electrodes in the micro-EDM process of $\mathrm{Ti}_{6} \mathrm{Al}_{4} \mathrm{~V}$ alloy. Surely, the aforementioned studies give some insight about suggestions for future research surveys.

The included studies are presented below in Table 1. They are characterized by the type of micro-EDMand the optimization method used.

Table 1. Set of included papers, their type of micro-EDM of $\mathrm{Ti}_{6} \mathrm{Al}_{4} \mathrm{~V}$ alloy and the optimization method

\begin{tabular}{|c|c|c|c|}
\hline Author Names & Article's Title & $\begin{array}{c}\text { Type of } \\
\text { micro-EDM }\end{array}$ & $\begin{array}{c}\text { Method of } \\
\text { Optimization }\end{array}$ \\
\hline Alavi \& Jahan, 2017 & $\begin{array}{l}\text { Optimization of process parameters in } \\
\text { micro-EDM of } \mathrm{Ti}-6 \mathrm{Al}-4 \mathrm{~V} \text { based on full } \\
\text { factorial design }\end{array}$ & Die-Sinking & Analysis of variance \\
\hline $\begin{array}{l}\text { Ali, Adesta, Rahman \& } \\
\text { Aris, } 2012\end{array}$ & $\begin{array}{l}\text { Powder Mixed Micro Electro Discharge } \\
\text { Milling of Titanium Alloy: Analysis of } \\
\text { Surface Roughness }\end{array}$ & $\begin{array}{l}\text { Milling, } \\
\text { Magnetic } \\
\text { assisted }\end{array}$ & $\begin{array}{l}\text { Analysis of variance } \\
\text { with multivariate } \\
\text { quadratic models }\end{array}$ \\
\hline $\begin{array}{l}\text { Aravind, Ganesh, Yasir, } \\
\text { Madhan-Mohan, } \\
\text { Krishnarah, \& Parthiban, } \\
2015\end{array}$ & $\begin{array}{l}\text { Experimental Investigation and Parameter } \\
\text { Optimization of Micro Holes Machining on } \\
\text { Ti-6Al-4V Alloy }\end{array}$ & Wedge & $\begin{array}{l}\mathrm{S} / \mathrm{N} \text { ratio plots and } \\
\text { analysis of variance }\end{array}$ \\
\hline Azad \& Puri, 2012 & $\begin{array}{l}\text { Simultaneous optimization of multiple } \\
\text { performance characteristics in micro-EDM } \\
\text { drilling of titanium alloy }\end{array}$ & Drilling & $\begin{array}{lr}\text { Taguchi } & \text { techniques } \\
\text { with a weighted } \\
\text { method }\end{array}$ \\
\hline $\begin{array}{l}\text { Barman, } \quad \text { Puri, } \\
\text { Nagahanumaiah, 2017 }\end{array}$ & $\begin{array}{l}\text { Analysis of Surface Texture of High Aspect } \\
\mathrm{Ratio} \text { Blind Micro Holes on Titanium Alloy } \\
\mathrm{Ti}_{6} \mathrm{Al}_{4} \mathrm{~V} \text { in Micro Electrical Discharge Drilling }\end{array}$ & Drilling & $\begin{array}{l}\text { Analysis of variance } \\
\text { with multivariate } \\
\text { quadratic models }\end{array}$ \\
\hline $\begin{array}{l}\text { Belloti, Qian, \& Reynaerts, } \\
2018\end{array}$ & $\begin{array}{l}\text { Enhancement of the micro-EDM process for } \\
\text { drilling through-holes }\end{array}$ & Drilling & $\begin{array}{ll}\text { Grey relational } \\
\text { analysis }\end{array}$ \\
\hline $\begin{array}{l}\text { Chow, Yan, Huang, \& } \\
\text { Hung, } 2000\end{array}$ & $\begin{array}{l}\text { Study of added powder in kerosene for the } \\
\text { micro-slit machining of titanium alloy using } \\
\text { electro-discharge machining }\end{array}$ & Micro-Slit & $\begin{array}{l}\text { One parameter at a } \\
\text { time }\end{array}$ \\
\hline $\begin{array}{l}\text { Chow, Yang, Lin, \& Chen, } \\
2008\end{array}$ & $\begin{array}{l}\text { The use of SiC powder in water as dielectric } \\
\text { for micro-slit EDM machining }\end{array}$ & Micro-Slit & $\begin{array}{l}\text { One parameter at a } \\
\text { time }\end{array}$ \\
\hline Huang, Yang, \& Hsu, 2018 & $\begin{array}{l}\text { The optimization of micro EDM milling of } \\
\text { Ti-6Al-4V using a grey Taguchi method and } \\
\text { its improvement by electrode coating }\end{array}$ & Milling & $\begin{array}{l}\text { Grey relational } \\
\text { analysis and Taguchi } \\
\text { techniques }\end{array}$ \\
\hline $\begin{array}{l}\text { Jithin, Kuriachen, \& } \\
\text { Mathew, } 2013\end{array}$ & $\begin{array}{l}\text { Modelling of } \mu \text {-ED Milling of Ti-6Al-4V } \\
\text { using RSM and ANN }\end{array}$ & Milling & $\begin{array}{l}\text { Artificial neural } \\
\text { network algorithm }\end{array}$ \\
\hline Kibria, \& Pradhan, 2012 & $\begin{array}{ll}\text { Multi-Criteria Optimization } & \text { of } \\
\text { Electro-Discharge Micro-Hole Machining of } \\
\text { Ti-6al-4v Super Alloy }\end{array}$ & Die-Sinking & $\begin{array}{l}\text { Grey relational } \\
\text { analysis and Taguchi } \\
\text { techniques }\end{array}$ \\
\hline Krishnaraj, 2016 & $\begin{array}{l}\text { Optimization of Process Parameters in } \\
\text { Micro-EDM of Ti-6Al-4V Alloy }\end{array}$ & Drilling & $\begin{array}{ll}\text { Analysis of variance } \\
\text { with } \\
\text { quadratic models }\end{array}$ \\
\hline Kumar \& Singh, 2018 & $\begin{array}{l}\text { Productivity improvement of micro EDM } \\
\text { process by improvised tool }\end{array}$ & Wedge & $\begin{array}{l}\text { One parameter at a } \\
\text { time }\end{array}$ \\
\hline $\begin{array}{l}\text { Kuriachen, \& Mathew, } \\
2014\end{array}$ & $\begin{array}{l}\text { Modeling of material removal mechanism in } \\
\text { Micro Electrical Discharge Milling of } \\
\text { Ti-6Al-4V }\end{array}$ & Milling & $\begin{array}{ll}\text { Analysis of variance } \\
\text { with } \\
\text { quadratic models }\end{array}$ \\
\hline $\begin{array}{l}\text { Kuriachen, \& Mathew, } \\
2015\end{array}$ & $\begin{array}{l}\text { Experimental Investigations into the Effects of } \\
\text { Microelectric-Discharge Milling Process } \\
\text { Parameters on Processing Ti-6Al-4V }\end{array}$ & Milling & $\begin{array}{l}\text { Analysis of variance } \\
\text { and 3D surface graphs }\end{array}$ \\
\hline $\begin{array}{l}\text { Kuriachen, \& Mathew, } \\
2016 \mathrm{a}\end{array}$ & $\begin{array}{l}\text { Effect of Powder Mixed Dielectric on Material } \\
\text { Removal and Surface Modification in } \\
\text { Microelectric Discharge Machining of } \\
\text { Ti-6Al-4V }\end{array}$ & Milling & $\begin{array}{l}\text { Analysis of variance } \\
\text { and 3D surface graphs }\end{array}$ \\
\hline $\begin{array}{l}\text { Kuriachen, \& Mathew, } \\
2016 b\end{array}$ & 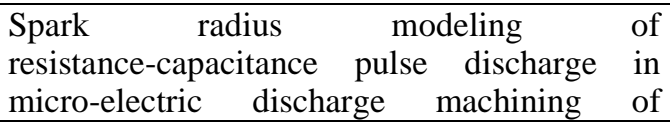 & Micro-Slit & $\begin{array}{l}\text { Analysis of Variance } \\
\text { with multivariate } \\
\text { quadratic models }\end{array}$ \\
\hline
\end{tabular}




\begin{tabular}{|c|c|c|c|}
\hline & Ti-6Al-4V: an experimental study & & \\
\hline $\begin{array}{l}\text { Kuriachen, Somashekhar, } \\
\text { \& Mathew, } 2014\end{array}$ & $\begin{array}{l}\text { Multiresponse optimization of micro-wire } \\
\text { electrical discharge machining process }\end{array}$ & Wedge & $\begin{array}{lr}\text { Fuzzy logic and } \\
\text { Particle } \\
\text { optimization }\end{array}$ \\
\hline $\begin{array}{l}\text { Lin, Chao, Huang, Wu, C } \\
\& \text { Hsu, } 2015\end{array}$ & $\begin{array}{l}\text { Use of the grey-Taguchi method to optimize } \\
\text { the micro-electrical discharge machining } \\
\text { (micro-EDM) of Ti-6Al-4V alloy }\end{array}$ & Milling & $\begin{array}{l}\text { Grey relational } \\
\text { analysis and Taguchi } \\
\text { techniques }\end{array}$ \\
\hline Meena, \& Azad, 2012 & $\begin{array}{l}\text { Grey Relational Analysis of Micro-EDM } \\
\text { Machining of Ti-6Al-4V Alloy }\end{array}$ & Drilling & $\begin{array}{ll}\text { Grey } & \text { relational } \\
\text { analysis } & \end{array}$ \\
\hline Mohanti, et al.,2018 & $\begin{array}{l}\text { Surface alloying using tungsten disulphide } \\
\text { powder mixed in dielectric in micro-EDM on } \\
\text { Ti6Al4V }\end{array}$ & Milling & $\begin{array}{l}\text { Grey relational } \\
\text { analysis and Taguchi } \\
\text { techniques }\end{array}$ \\
\hline Parveen \& Jahan, 2108 & $\begin{array}{l}\text { Modeling and optimization of crater size } \\
\text { generated during micro- EDM of } \mathrm{Ti} \text { alloy } \\
\text { using Response surface method }\end{array}$ & Drilling & $\begin{array}{ll}\text { Analysis of variance } \\
\text { with multivariate } \\
\text { quadratic models }\end{array}$ \\
\hline $\begin{array}{l}\text { Parveen, Jahan, } \quad \& \\
\text { Zhugagulova, } 2018\end{array}$ & $\begin{array}{l}\text { Statistical Modeling and Optimization of } \\
\text { Micro Electro Discharge Machining of } \mathrm{Ti} \\
\text { Alloy }\end{array}$ & Drilling & $\begin{array}{l}\text { Analysis of variance } \\
\text { with multivariate } \\
\text { quadratic models }\end{array}$ \\
\hline Phipon \& Pradhan, 2012 & $\begin{array}{l}\text { Process Parameters Optimization of Micro } \\
\text { Electric Discharge Machining Process Using } \\
\text { Genetic Algorithm }\end{array}$ & Drilling & Genetic algorithm \\
\hline Plaza, et al., 2014 & $\begin{array}{l}\text { Experimental study on micro EDM-drilling of } \\
\text { Ti6Al4V using helical electrode }\end{array}$ & Drilling & $\begin{array}{l}\text { One parameter at a } \\
\text { time technique }\end{array}$ \\
\hline $\begin{array}{l}\text { Pradhan \& Bhattacharyya, } \\
2008\end{array}$ & $\begin{array}{l}\text { Improvement in microhole machining } \\
\text { accuracy by polarity changing technique for } \\
\text { microelectrode discharge machining on } \\
\text { Ti--6Al--4V }\end{array}$ & Drilling & $\begin{array}{l}\text { One parameter at a } \\
\text { time technique }\end{array}$ \\
\hline $\begin{array}{l}\text { Pradhan, \& Bhattacharyya, } \\
2009\end{array}$ & $\begin{array}{l}\text { Modelling of micro-electro discharge } \\
\text { machining during } \\
\text { machining of titanium alloy } \mathrm{Ti}-6 \mathrm{Al}-4 \mathrm{~V} \text { using } \\
\text { response surface methodology and artificial } \\
\text { neural network algorithm }\end{array}$ & Drilling & $\begin{array}{l}\text { Artificial neural } \\
\text { network algorithm }\end{array}$ \\
\hline $\begin{array}{l}\text { Pradhan, Masanta, Sarkar, } \\
\text { \& Bhattacharyya, } 2009\end{array}$ & $\begin{array}{l}\text { Investigation of electro-discharge } \\
\text { micro-machining of titanium super alloy }\end{array}$ & Drilling & Taguchi techniques \\
\hline Sapkal \& Jagtap, 2018 & $\begin{array}{l}\text { Optimization of Micro EDM Drilling Process } \\
\text { Parameters for Titanium Alloy by Rotating } \\
\text { Electrode }\end{array}$ & Drilling & Analysis of variance \\
\hline $\begin{array}{l}\text { Singh, Yadava, \& Narayan, } \\
2018\end{array}$ & $\begin{array}{l}\text { Parametric study of ultrasonic-assisted hole } \\
\text { sinking micro-EDM of titanium alloy }\end{array}$ & $\begin{array}{l}\text { Hole-sinking, } \\
\text { Ultrasonic } \\
\text { assisted }\end{array}$ & Analysis of variance \\
\hline $\begin{array}{l}\text { Sivaprakasam, Hariharan, } \\
\text { \& Gowri, 2014a }\end{array}$ & $\begin{array}{l}\text { Analysis of Machining Parameters of } \\
\mu \text {-WEDM on Titanium Alloy }\end{array}$ & Wedge & Analysis of variance \\
\hline $\begin{array}{l}\text { Sivaprakasam, Hariharan, } \\
\text { \& Gowri, 2014b }\end{array}$ & $\begin{array}{l}\text { Modeling and analysis of micro-WEDM } \\
\text { process of titanium alloy (Ti-6Al-4V) using } \\
\text { response surface approach }\end{array}$ & Wedge & $\begin{array}{l}\text { Analysis of variance } \\
\text { and Genetic algorithm }\end{array}$ \\
\hline $\begin{array}{l}\text { Tiwary, Pradhan, } \\
\text { Bhattacharyya, } 2013\end{array}$ & $\begin{array}{l}\text { Parametric Optimization of Micro-EDM } \\
\text { Process Using Response Surface Methodology } \\
\text { and Principal Component Analysis }\end{array}$ & Drilling & $\begin{array}{l}\text { Principal component } \\
\text { analysis }\end{array}$ \\
\hline $\begin{array}{l}\text { Tiwary, Pradhan, } \\
\text { Bhattacharyya, } 2014 \mathrm{a}\end{array}$ & $\begin{array}{l}\text { Study on the influence of micro-EDM process } \\
\text { parameters during machining of } \mathrm{Ti}-6 \mathrm{Al}-4 \mathrm{~V} \\
\text { superalloy }\end{array}$ & Die-Sinking & $\begin{array}{l}\text { Analysis of variance } \\
\text { with multivariate } \\
\text { quadratic models }\end{array}$ \\
\hline $\begin{array}{l}\text { Tiwary, Pradhan, } \\
\text { Bhattacharyya, } 2014 \mathrm{~b}\end{array}$ & $\begin{array}{l}\text { Application of multi-criteria decision-making } \\
\text { methods for selection of micro-EDM process } \\
\text { parameters }\end{array}$ & Drilling & Fuzzy logic \\
\hline $\begin{array}{l}\text { Tiwary, Pradhan, } \quad \& \\
\text { Bhattacharyya, } 2018\end{array}$ & $\begin{array}{l}\text { Parametric Optimization of Micro-EDM } \\
\text { Process during Micro-hole Machining on } \\
\text { Ti-6Al-4V using WASPAS Method }\end{array}$ & Drilling & WASPAS method \\
\hline
\end{tabular}

The predominance of Indian authors was surprisingly high: (74 \%) of the total number of articles were published by researchers working in Indian institutions. Second to them, researchers working in Taiwan institutions published (10 \%) of the total number of articles. 
Most studies were dealing with drilling micro-EDM process (44\%) and then with milling (24\%). Undoubtedly, the vast majority of studies used multiple linear regression models, mainly quadratic, for the description of the behavior of the variables.

In the following graph, the number of publications per year is given.

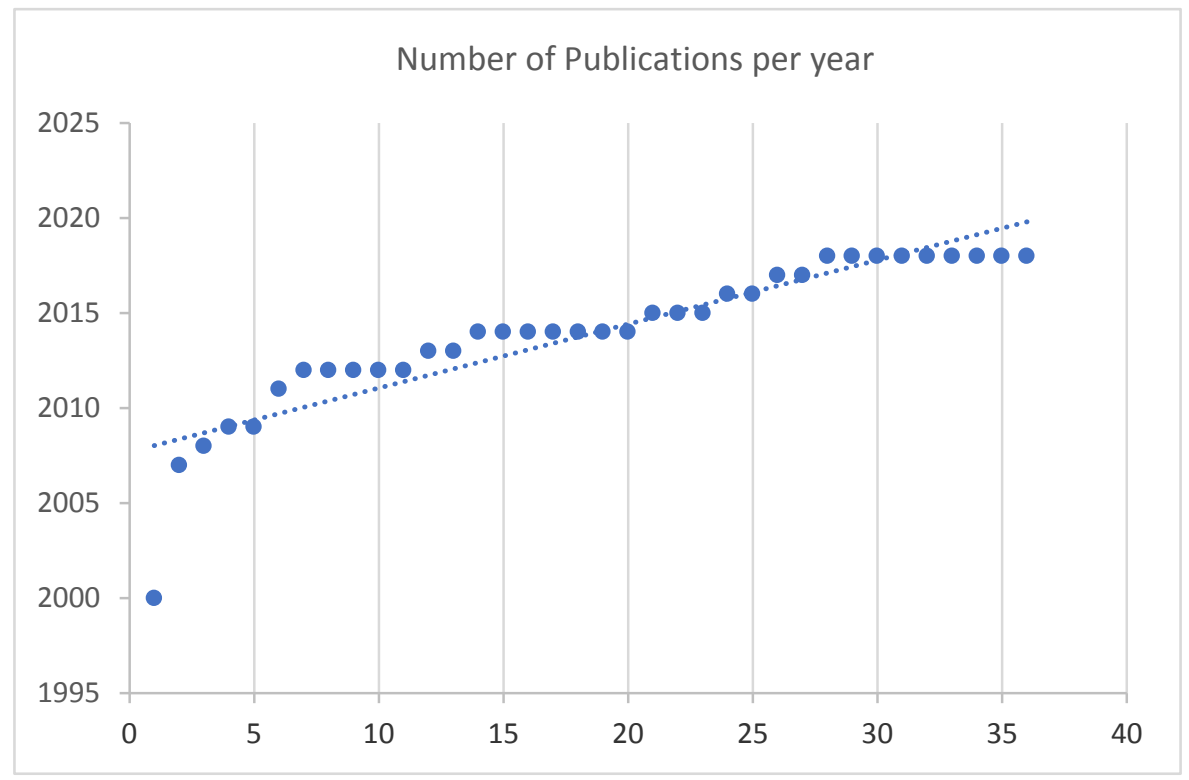

Figure 1. The distribution of articles over two decades

\subsection{Optimization Techniques}

In this section, we will give an answer to the first research question. In the papers that passed the criteria a total of eight optimization techniques were used and shown in Table 1.

In the following sections, we will investigate the techniques.

\subsubsection{One Variable at a Time}

The technique One Variable at a Time describes the effects of a single variable on the response, but it ignores the possible effects of other independent variables. In this case, the mean square error (MSE) of the analysis of variance contains the effects of omitted variables, so it will be inflated and consequently it is not a good estimate of the random error.

However, in many cases the authors wanted to investigate the efficiency of newly designed or modified settings of their experiments, by evaluating the response variables at various levels of a single process variable. More specifically:

Twenty years ago, Chow, Yan, Huang and Hung (2000) experimented with the effects of various dielectric fluids such as kerosene or kerosene with added Al powder or kerosene with added Sic powder, by varying pulse on time, powder concentration, and electrode revolution, one variable at a time. They found that the optimal concentration for added $\mathrm{Al}$ or $\mathrm{SiC}$ powders was reached at $5 \mathrm{~g} / \mathrm{l}$ and $20 \mathrm{~g} / \mathrm{l}$ respectively, and these values were fixed in their following experiments as the standard concentration for either powders. They observed that added Sic produced the highest material removal depth and microhardness amongst the different dielectric fluids, and the added powders achieved finest surface roughness. The largest value of material removal depth was reached for a pulse of medium duration, but it decreased for higher pulse duration for the three different dielectrics. Similar results were obtained for the electrode rotation speed (Chow, Yan, Huang, \& Hung, 2000).

Huang, Yang and Hsu (2018) used pure water with Sic powder as a dielectric, and determined the optimum concentration powder level at $25 \mathrm{~g} / \mathrm{l}$. Then, they fixed all the parameters at some levels and the powder concentration at optimum level and confirmed that negative polarity machining yields a micro-slit ten times deeper than that obtained with positive polarity, and that the MRR reaches its largest value for a pulse of medium duration. Pure water with added powder resulted in refinement of surface roughness, highest attainment of MRR, greater slit expansion and lowest machined burr. In both studies they ascertained that the electrode gained a lower wear rate for kerosene (or pure water) alone than that for kerosene (or pure water) with added powders (Huang, Yang, \& Hsu, 2018).

Pradhan and Bhattacharyya (2008) reversed the polarity of the tool, intermittently at exponentially decreasing time intervals and compared the influence of current firstly, and then of the pulse duration on many quality surface variables; 
they found that pulse on time in the range of (1-10 $\mu \mathrm{s})$ and peak current below (1 A) with changing polarity are more effective in improving the machining accuracy of straight-through micro holes (Pradhan \& Bhattacharyya, 2008).

Plaza et al., (2014) investigated the production of best quality holes and found that the use of CuW as the electrode material among various materials was the best option for improving high aspect-ratio holes and a $\mathrm{CuW}$ electrode with diameter equal to $800 \mu \mathrm{m}$ among different choices of diameters achieved the maximum hole depth. Then, the influence of the helical angle and the flute depth had been addressed. It was found that when using electrode of helix angle of $45^{\circ}$ and flute depth of $50 \mu \mathrm{m}$ there were a $37 \%$ decrease in machining time and an additional $19 \%$ reduction with flute depth of $150 \mu \mathrm{m}$. Higher angles result in higher machining time and the greatest hole depth were realized with the greater flute depth. Also, tip regeneration, their new strategy in which the helical shaped electrode was re-sharpened by EDM cutting the damaged tip in the same machine where the micro drilling took place, improved the hole depth (Plaza et al., 2014).

Kumar and Singh (2018) fabricated a new electrode by cutting micro slots in the solid cylindrical electrode at $60^{\circ}$ and $75^{\circ}$ to the horizontal. By using as process parameters, inclination angle, slot width and tool speed, one parameter at a time, they compared the performance of the tool electrode with decline micro-slot(s) and cylindrical electrode while keeping voltage, discharge energy and current constant. They found that, compared to the solid cylindrical electrodes the multiple slotted electrodes increased the aspect ratio by $300 \%$ for a hole diameter of $0.8 \mathrm{~mm}$. Also, for slotted electrodes, the critical depth was found to be equal to the height of the slot from the tool base and depended on the angle of the slot: lower the angle, higher was the critical depth. Beyond this depth, the machining time increased. A slotted electrode with slot angle of $75^{\circ}$ increased the MRR and the aspect ratio and had the minimum machining time at slot width of $150 \mu \mathrm{m}$ and the tool speed of $1000 \mathrm{rpm}$ (Kumar \& Singh, 2018).

\subsubsection{ANOVA and Multiple Regression Models}

In this section, studies that developed multi-factor models will be analyzed and all process parameters will be given together with their levels, which are written in brackets, because the range of values plays a very important role in the statistical analysis.

The experiments in the studies were carried out adopting a full factorial design (Sivaprakasam et al., 2014; Barman et al., 2017; Alavi, \& Jahan, 2017; Ali et al., 2012; Kuriachen, \& Mathew, 2016; Parveen et al., 2018), Box Behnken design (Kuriachen, \& Mathew, 2016; Kuriachen \& Mathew, 2015; Parveen \& Jahan, 2018; Kuriachen \& Mathew 2014), central design of experiment ( Sapkal \& Jagtap, 2018), rotatable central composite design (Tiwary, Pradhan, \& Bhattacharyya, 2014), or orthogonal array design (Krishnaraj, 2016). The machining factors were varied almost in all experiments at three levels.

In the above studies, ANOVA was used to detect significant input parameters (Kuriachen \& Mathew, 2015; Kuriachen \& Mathew, 2016; Sapkal \& Jagtap, 2018; Alavi \&Jahan, 2017; Singh et al.,2018). In other studies, researchers continued with developing multi-regression models (Ali et al., 2012; Barman et al., 2017; Plaza et al., 2014; Pradhan \& Bhattacharyya, 2008; Parveen \&Jahan, 2018; Kuriachen \& Mathew, 2014; Kumar \&Singh, 2018; Kuriachen \& Mathew, 2016; Parveen et al., 2018;Tiwary et al., 2014). The analysis of variance is the classical way for assessing the contribution of explanatory variables in the models. Each process variable accounts for a certain amount of the total variance of the response variable and their relative contributions, and in some cases, can be quantified. The percentage contribution of the input variables is reliable in design experiments in which the effects of each explanatory variable are orthogonal; otherwise the order we consider the variables is very important and the contribution is due to selected combined effects. We cannot rely on an ANOVA model for conclusions about the accuracy of predictions, hence, further investigation is needed. Also, the ANOVA table provides a formal $\mathrm{F}$ test for the factor effects and their statistical significance. However, $\mathrm{F}$ values follow a distribution which depends on the number of predictor variables in the model: the more predictors added to the model the greater $\mathrm{F}$ will be (and the smaller $\mathrm{p}$ will be).

In the studies where ANOVA techniques were applied the following quality parameters were mainly investigated:

Material Removal Rate (MRR): Kuriachen and Mathew (2016) chose as process parameters powder concentration (g/l) $\{5,15,25\}$, capacitance $(\mu \mathrm{F})\{0.01,0.1,0.4\}$, and voltage $(\mathrm{V})\{80,115,150\}$ and reported that the MRR increases up to an optimum level of capacitance and voltage; max MRR is obtained at low levels of SiC powder concentration and middle levels of capacitance and voltage, in milling micro-EDM machining process. Thus, they changed their previously reported results confirming that voltage capacitance, electrode rotation speed and feed rate increase proportionally to the MRR (Kuriachen \& Mathew, 2016; Kuriachen \& Mathew, 2015). Krishnaraj (2016) used an L9 orthogonal array to conduct the experiments and reported that peak current and pulse on time significantly influence and have the maximum percentage contribution to the MRR (50.64\%, 35.38\% respectively), but for higher values of pulse on time the MRR is slightly affected (Krishnaraj, 2016). Sapkal and Jagtap (2016) reported that a combination of higher level of voltage (150 V) and electrode rotation speed $(2500 \mathrm{rpm})$ and lower level of capacitance $(100 \mathrm{pF})$ while pulse on time near to high values $(59.1$ $\mu \mathrm{s})$ lead to the best values for taper ratio (0.0179), side gap width $(0.0889)$ and MRR $(0.0025 \mathrm{mg} / \mathrm{s})$ in drilling machining 
process (Sapkal \& Jagtap, 2018). Tiwary et al., (2014) by investigating the 3D surface plots found that the MRR gradually increases with the increase in peak current (when peak current is sorted by voltage from low to high values), but it decreases after the middle levels. MRR increases proportionally with the increase of voltage (sorted by peak current) in die-sinking micro-EDM machining process (Tiwary et al., 2014).

Electrode Ware Rate (EWR): It has been reported that EWR increases rapidly with the increase in peak current (sorted by voltage), but it decreases monotonically with the increase in voltage gap (Tiwary et al., 2014). Similarly, it was found that the peak current and pulse on time affect the most EWR and produce the maximum percentage contribution, 48.18\%, $28.55 \%$ respectively, and EWR increases proportionally with $t_{\text {on }}$ (Krishnarah, 2016). Alavi and Jahan (2017) chose as machining parameters the capacitance $(\mathrm{pF})\{30,1000,4700\}$, servo voltage $(\mathrm{V})\{60,90$, 112 $\}$, electrode rotation speed(rpm) $\{1000,3000,4500\}$, and coating of the electrodes. They reported that the capacitance is the most important parameter for electrode wear and the increase in capacitance results in reduction of tool wear percentage contribution $(89.43 \%)$. They also found some two-way parameters interactions significant for tool wear but with an almost negligible contribution in die sinking micro-EDM process. It was suggested that the optimum values for machining time (237 s), tool wear $(0.003 \mathrm{~mm})$, crater size $(0.00126 \mathrm{~mm})$ and microhardness $(477.5 \mathrm{HV})$ were obtained at low level of voltage, high level of capacitance, middle level of electrode rotational speed and with WC electrode with TN coating ( Alavi \&Jahan, 2017).

Overcut (OC): OC increases with the increase in pulse on time up to the middle levels and then it decreases; it also increases with the increase in peak current (Tiwary et al., 2014).

Taper: Peak current significantly affects taper. Tiwary et al. (2014) reported that with the increase in peak current taper gradually decreases and at low flushing pressure the highest taperness is observed, but the increase in pressure results in decrease in taper. Krishnarah (2016) found that peak current is a statistically significant factor for taper with percentage contribution $(88.51 \%)$ to the quality of the hole, but he reported that taper increases when pulse on time increases; flushing pressure does not have any significant effects on taper (Krishnarah, 2016).

Crater size: Voltage was reported as the most important in machining time with percentage contribution (65.79\%) and in crater size with percentage contribution (89.09\%) (Alavi \&Jahan, 2017).

Surface Roughness: Ali et al. (2012) confirmed that energy's low level combined with high powder concentration results in low surface roughness, in milling micro-EDM; minimum value of $R a(0.75 \mu \mathrm{m})$ can be achieved with $(83 \%)$ desirability for $(16.8 \mathrm{~g} / \mathrm{L}) \mathrm{SiC}$ powder concentration and $(57.8 \mu \mathrm{J})$ energy discharge (Ali et al., 2012).

We can conclude that peak current, voltage, capacitance time duration are the most important indicators in influencing the machining performance. However, in a few studies some more parameters are investigated like:

Ultrasonic power: The ultrasonic vibration in hole-sinking micro-EDM was found to make smoother, free of debris and more circular micro holes, and to improve the effects of other machining parameters: TWR and taper decrease significantly at middle and high levels of gap current when combined with increase of ultrasonic power, but in low levels of gap current gradual increment in TWR and taper is observed with increase in ultrasonic power (Singh et al., 2018).

In the studies mentioned in Table 2, the researchers described predictive models of response variables in more than one process parameters predictors, together with optimal parametric settings. 
Table 2. Optimization Technique presented in each paper

\begin{tabular}{|c|c|c|c|}
\hline & Process Variables & Multiple Regression Equation & $\begin{array}{l}\text { Optimal } \\
\text { parametric } \\
\text { settings }\end{array}$ \\
\hline $\begin{array}{l}\text { Ali et } \\
\text { al., } \\
2012\end{array}$ & $\begin{array}{c}\text { Powder } \\
\text { concentration: } \\
\text { PC }(\mathrm{g} / \mathrm{L}): \\
\{10,15,20,25\} \\
\mathrm{E}(\mu \mathrm{J}): \\
\{36.13,46.13,55.1 \\
5,66.13\}\end{array}$ & $R_{a}(\mu m)=103.5-11.6 *(P C)-0.55 * E+0.33 *(P C)^{2}$ & $\begin{array}{c}\mathrm{PC}=16.8 \mathrm{~g} / \mathrm{L} \\
\mathrm{SiC}, \mathrm{E}=57.8 \\
\mu \mathrm{J} \\
\begin{array}{c}\text { and } R_{a}=0.75 \\
\boldsymbol{\mu m}\end{array}\end{array}$ \\
\hline $\begin{array}{l}\text { Barma } \\
\text { n et.al., } \\
2017\end{array}$ & $\begin{array}{c}\mathrm{D}(\mathrm{mm}):\{2,2.5, \\
\quad 3\} \\
\mathrm{C}(\mathrm{nF}): \quad\{1,10, \\
100\} \\
\mathrm{V}(\mathrm{V}): \begin{array}{c}\{90,120, \\
150\}\end{array}\end{array}$ & $\begin{array}{c}\mathrm{Ra}(\mu \mathrm{m})=1.55+0.1 * D+0.53 * C+0.17 * V+0.19 * C^{2}- \\
0.03 * V^{2}-0.02 D * C+0.01 * D * V+0.02 * C * V \\
\mathrm{Sa}(\mu \mathrm{m})=3.57+0.09 * D+0.67 * C+0.12 * V+0.04 * C^{2}- \\
\\
0.02 * V^{2}+0.02 * D * C+0.03 * C * V\end{array}$ & $\begin{array}{c}\mathrm{V}=90 \mathrm{~V}, \mathrm{C}= \\
1 \mathrm{nF}, \\
\mathrm{D}=2 \mathrm{~mm} . \\
\text { Process output } \\
\mathrm{Ra}=0.9226 \\
\mu \mathrm{m} \text { and } \mathrm{Sa}= \\
2.7525 \mu \mathrm{m} .\end{array}$ \\
\hline $\begin{array}{l}\text { Krishn } \\
\text { araj } \\
2016\end{array}$ & $\begin{array}{c}\mathrm{I}(\mathrm{A}):\{1.5,2.5, \\
3.5\} \\
t_{o n}(\mu s):\{6,8,10\} \\
\left.F_{p}(M P a)\right): \\
\{0.08,0.12,0.16\}\end{array}$ & $\begin{array}{c}\operatorname{MRR}(\mathbf{g} / \mathbf{m i n})=-1.082+0.295 * \mathrm{I}+0.133 * t_{o n}+5 * \mathrm{~F}-0.034 * I^{2}- \\
0.005 * t_{o n}^{2}-24.708 * F^{2}\end{array}$ & $\begin{array}{c}\mathrm{I}=1.5 \mathrm{~A}, \\
t_{\text {on }}=6 \mu \mathrm{s}, \\
\mathrm{F}=0.08 \mathrm{MPa}, \\
\text { and } \\
\mathrm{MRR}=0.00064 \\
5 \mathrm{~g} / \mathrm{min}\end{array}$ \\
\hline $\begin{array}{l}\text { Kuriac } \\
\text { hen } \\
\& \\
\text { Mathe } \\
\text { W } \\
2014\end{array}$ & $\begin{array}{c}\mathrm{V}(\mathrm{V}):\{80,115, \\
150\} \\
\mathrm{C}(\mu F): \\
\{10,100,400\} \\
\text { ERS }(\mathrm{rpm}):\{500, \\
1000,1500\} \\
\text { FR }(\mathrm{mm} / \mathrm{min}): \\
\{6,12,18\}\end{array}$ & $\begin{array}{c}\text { MRR (mg/hr) }=0.66+0.03 * V+0.1 * C+0.6 *(E R S)+ \\
0.24 * F R+0.10 C *(F R)-0.06 * V^{2}-0.15 * C^{2}-0.06 * \\
(E R S)^{2}\end{array}$ & $\begin{array}{c}\mathrm{V}=115 \mathrm{~V}, \\
\mathrm{C}=400 \mathrm{nF}, \\
\mathrm{ERS}= \\
1000 \mathrm{rpm}, \mathrm{FR}= \\
18 \mathrm{~mm} / \mathrm{min}\end{array}$ \\
\hline $\begin{array}{l}\text { Kuriac } \\
\text { hen } \\
\& \\
\text { Mathe } \\
\text { W } \\
2016\end{array}$ & $\begin{array}{c}\text { C(nF): }\{1 \\
1000,2200\} \\
V(V):\{80,115 \\
150\}\end{array}$ & $\begin{aligned} \text { Spark Radius }(\boldsymbol{\mu m})= & 21.47+0.03 * C-0.05 * V+1.47 * 10^{-4} * \\
& C * V-1.27 * 10^{-5} * C^{2}\end{aligned}$ & $\begin{array}{l}\mathrm{C}=2200 \mathrm{nF} \\
\mathrm{V}=150 \mathrm{~V} \text { and } \\
\text { max spark } \\
\text { radius }=62 \mu \mathrm{m}\end{array}$ \\
\hline $\begin{array}{l}\text { Parvee } \\
\text { n \& } \\
\text { Jahan } \\
2018\end{array}$ & $\begin{array}{c}\mathrm{C}(\mathrm{pF}):\{0.03,1 \\
4.7\} \\
\mathrm{V}(\mathrm{V}):\{60,85 \\
100\} \\
\text { ERS (rpm): }\{1000 \\
2000,3000\}\end{array}$ & $\begin{array}{c}\mathrm{c}(\boldsymbol{\mu m})=5.88+4.48 * C+0.94 * V+0.35 *(E R S)+0.14 * C^{2}+ \\
0.53 * V^{2}-1.06 *(E R S)^{2}+0.02 C * V+0.32 * C *(E R S)+ \\
0.36 * V *(E R S)\end{array}$ & \\
\hline $\begin{array}{l}\text { Parvee } \\
\text { n et al., } \\
2018\end{array}$ & $\begin{array}{l}\mathrm{V}(\mathrm{V}):\{60,110\} \\
\mathrm{C}(\mathrm{nF}):\{0.03,4.7\} \\
\text { ERS: }\{1000 \\
\text { 3000] }\end{array}$ & $\begin{array}{c}\text { Overcut }(\boldsymbol{\mu m})=15.57+1.38 * V+2.70 * C+2.05 * E R S+ \\
0.05 * V * C+1.25 C *(E R S)+1.28 * V *(E R S)+0.1 V * C * \\
(E R S) \\
\operatorname{TR}(\boldsymbol{\mu m})= \\
40.34-7.36 * \mathrm{~V}-10.74 * \mathrm{C}+3.18 *(\mathrm{ERS})-0.3 * \mathrm{~V} * \mathrm{C}+0.62 * \mathrm{C} *(\mathrm{ERS})+1.28 * \\
\mathrm{~V} *(\mathrm{ERS})-0.31 * \mathrm{~V} * \mathrm{C} *(\mathrm{ERS})\end{array}$ & \\
\hline $\begin{array}{l}\text { Tiwary } \\
\text { et al., } \\
2014\end{array}$ & $\begin{array}{c}t_{\text {on }}(\mu s):\{1,4,8,12,1 \\
\text { I }(\mathrm{A}):\{0.5,1,1.5,2, \\
\mathrm{V}(\mathrm{V}): \\
\{30,35,40,45,50\} \\
F_{p}\left(\mathrm{~kg} / \mathrm{cm}^{2}\right): \\
\{0.15,0.25 .0 .30,0 \\
35\}\end{array}$ & $\begin{array}{c}\text { MRR (mg/min })=0.043+0.01 * t_{\text {on }}+0.003 * I-0.002 * V- \\
0.002 * F_{p}-0.001 *\left(t_{o n}\right)^{2}-0.002 * I^{2}-0.0607 * V^{2}+0.002 * \\
\left(F_{p}\right)^{2}-0.0001 * t_{o n} * I+0.0001 * t_{o n} * V+0.0007 * t_{o n} * F_{p}+ \\
0.002 I * V-0.003 * I * F_{p}-0.002 * V * F_{p}\end{array}$ & $\begin{array}{c}t_{\text {on }}=1 \mu \mathrm{s}, \\
\mathrm{I}=2.5 \mathrm{~A}, \mathrm{~V}=50 \\
\mathrm{~V}, \\
\mathrm{Fp}=0.20 \\
\mathrm{~kg} / \mathrm{cm}^{2} \\
\mathrm{MRR}=0.0777 \\
\mathrm{mg} / \mathrm{min}, \\
\mathrm{TWR}=0.0088 \\
\mathrm{mg} / \mathrm{min}, \\
\mathrm{OC}=0.0765 \\
\mathrm{~mm}, \\
\text { taper }=0.0013\end{array}$ \\
\hline
\end{tabular}


All the models are quadratic with interactions, but we cannot compare them because any two of them either have the same dependent variable but differ in one or more independent variables or they are models of different quality variables in the same predictors.

The coefficients of the quadratic models do not offer relevant information, like in linear regression, since the coefficients of the variables of interactions cannot be easily interpreted.

Thus, the models can be used only for predictive purposes. The coefficient of determination $\left(R^{2}\right), \operatorname{Adj}\left(R^{2}\right), \operatorname{Predicted}\left(R^{2}\right)$ help decide if the model that we can form, always based on our data and well-known formulas, has a strong predictability. $\left(R^{2}\right)$ is a very important index giving the part of variation of the values of quality variable that is explained by the model. In almost all the above models $\left(R^{2}\right)$ is very close to one, which means that the model fits very well the data. But together with $\left(R^{2}\right)$, many more indexes must be investigated in order to assure the reliability of the model: Adj $\left(R^{2}\right)$ examines if there are not many predictors in the model, known as overfitting of the model, and consequently $R^{2}$ is misleading because the additional predictors cause its increase. If $\operatorname{Adj}\left(R^{2}\right)$ is considerably different from $\left(R^{2}\right)$, like the one found by Sapkal and Jagtap (2018), where the two coefficients are $(88.39 \%)$ and $(78.28 \%)$, the model must be re-investigated. Predicted $\left(R^{2}\right)$ indicates how well a regression model predicts new observations. If $\left(R^{2}\right)$ and $\operatorname{Adj}\left(R^{2}\right)$ look quite reasonable but Predicted $\left(R^{2}\right)$ is not close to 1 , then the only thing that we do is to excessively bend the fitted surface and artificially connect the dots rather than finding a helpful relationship among the variables.

In the study of the models, the lack of fit test is very important because if the test is statistically significant then it is necessary to add predictors of higher order. However, in almost all the above studies this test is not mentioned in the results.

The residual standard deviation is a number that must be mentioned constantly because compared to the standard deviation of the coefficients give an insight about the validity of the model. Again, these numbers are missing from the manually reproduced outputs.

In conclusion, many of the above models must be given together with the full output for deciding about their reliable predictability.

\subsubsection{Grey Relational Analysis-Taguchi Methods}

For the technique Grey Relational Analysis-Taguchi methods, the authors apply Taguchi methods to optimize process parameters and improve quality characteristics, specifically to maximize (MRR) and minimize (TWR), overcut, and taperness in micro-EDM of $\mathrm{Ti}_{6} \mathrm{Al}_{4} \mathrm{~V}$ alloy. The method uses a special class of Design of Experiment called orthogonal arrays (OA); these standard arrays specify the way of conducting the minimal number of experiments with many process variables and give the information that is obtained when using a full factorial design. The objective of the method is to find the controllable process parameters settings for which noise (variation of the variables that are impossible or expensive to control) has a minimal effect on the process's functional characteristics. At this point, we must insist on the importance of the choice of the factor levelssince the Taguchi method determines the significance and optimal set of values within the chosen levels. Thus, if engineers choose a wide range of factor levels then the optimal set of values will be vague and misleading. If engineers choose a very narrow range of factors levels, then the ANOVA results will not be significant.

For each experiment, a series of new experiments are conducted by varying the level settings and by repeating the same runs. The experimental data are converted, with a mathematical log equation, into $\mathrm{S} / \mathrm{N}$ ratios which measures the influence of noise. Then, ANOVA on the average $\mathrm{S} / \mathrm{N}$ ratios of each performance variable indicates which machining factor dominates over the others and the percentage contribution of that factor. The highest S/N of the machining parameters levels indicate the optimal level of each output variable.

Another technique used by the authors is Grey Relational Analysis developed by Professor J. Deng. In this method, the experimental data are normalized in order to overcome the problem of different units and magnitudes. Then, the grey relational coefficients are calculated for each quality parameter and at each experiment; their average for all the quality parameters at each experiment gives the grey relational grade. The grey relational grade describes the relationship among the factors and determines the important factors (by order) that significantly influence our objectives of MRR maximization and EWR and overcut minimization simultaneously and effectively.

Consequently, with Taguchi method, we determine a set of parametric settings for each of the quality variables. Although, with grey relational analysis, a single parametric set of values for all the quality variables is determined.

Some authors combined both techniques by applying grey relational analysis to the $\mathrm{S} / \mathrm{N}$ ratios of Taguchi method. In this case, the $\mathrm{S} / \mathrm{N}$ ratios undergo the normalization process, and they find the Grey relational coefficients and the grey relational grades of the normalized data. They perform ANOVA for the quality characteristics using the calculated values for the grey relational grades. In that way, they find the most significant factors which control all the quality 
characteristics simultaneously. Another technique is to compute the grey relational grades, and then apply Taguchi method on these data. The related studies are the following by chronological order.

Pradhan et al. (2009) chose as control factors Peak Current (A) $\{0.5,1,1.5\}$, Pulse on time ( $\mu$ s) $\{1,10,20\}$, Flushing Pressure $\left(\mathrm{kg} / \mathrm{cm}^{2}\right)\{0.1,0.3,0.5\}$ Duty ratio $(\%)\{60,80,95\}$ and L9 orthogonal array design of experiment. They transformed the measurements of MRR into S/N ratios of the larger the better characteristic and the measurements of TWR, overcut and taper into S/N ratios of the smaller the better characteristic. They applied ANOVA for the average S/N ratios at its level of the control factors to determine their relative significance and found that only peak current and pulse on time had significant effects on the quality variables. Pulse on time had the maximum percentage contribution to MRR, overcut and taper with second most influential factor peak current which, on the other hand, was the most influential on TWR. They analyzed the $\mathrm{S} / \mathrm{N}$ ratio curves and determined the optimal settings for each quality variable separately: higher MRR: $1.5 \mathrm{~A} / 10 \mu \mathrm{s} / 0.5 \mathrm{~kg} / 95 \%$, least TWR: $0.5 \mathrm{~A} / 1 \mu \mathrm{s} / 0.3 \mathrm{~kg} / \mathrm{cm}^{2} / 60$, least overcut: $0.5 \mathrm{~A} / 1 \mu \mathrm{s} / 0.1 \mathrm{~kg} / \mathrm{cm}^{2} / 60 \%$ and least taper: $1.5 \mathrm{~A} / 10 \mu \mathrm{s} / 0.5 \mathrm{~kg} / \mathrm{cm}^{2} / 95 \%$. In this original work, the computation of the $\mathrm{S} / \mathrm{N}$ ratios have been performed wrongly: each $\mathrm{S} / \mathrm{N}$ ratio was calculated as $-10 \log \left(\mathrm{y}^{2}\right)$, where $\mathrm{y}$ is the average of the three experimentally obtained data, $\mathrm{y}_{1}, \mathrm{y}_{2}, \mathrm{y}_{3}$, in the three repetitions of the same run although the formula asks for $-10 \log \left(1 / 3 \sum \mathrm{yi}^{2}\right)$. Consequently, with the wrong computation, the noise caused by the uncontrolled factors was ignored. Also, the range of the levels of pulse on time is wide and probably affected their final optimal settings.

Kibria and Pradhan (2012) chose as control factors Peak Current (A) $\{0.5,1,1.5\}$, Pulse on time ( $\mu$ s) $\{5,10,20\}$, Flushing Pressure $\left(\mathrm{kg} / \mathrm{cm}^{2}\right)\{0.1,0.3,0.5\}$, and Taguchi method for L9, and applied Taguchi method for determining the optimal factor settings for each quality variable. Next, they determined multiple regression models for each of their quality variables and by applying the optimal settings in each of these equations they found the values of the quality variables at the optimal settings. Their multi-optimization sets were: higher MRR $(0.007951 \mathrm{mg} / \mathrm{min})$ at $1.5 \mathrm{~A} / 10 \mu \mathrm{s} / 0.5 \mathrm{~kg} / \mathrm{cm}^{2}$, least TWR $(0.000708 \mathrm{mg} / \mathrm{min})$ at $1.5 \mathrm{~A} / 20 \mu \mathrm{s} / 0.5 \mathrm{~kg} / \mathrm{cm}^{2}$, least overcut $(0.03465 \mathrm{~mm})$ at $1.5 \mathrm{~A} / 5 \mu \mathrm{s} / 0.5 \mathrm{~kg} / \mathrm{cm}^{2}$ and least taper at $0.5 \mathrm{~A} / 5 \mu \mathrm{s} / 0.3 \mathrm{~kg} / \mathrm{cm}^{2}$. Then, they applied separately grey relational analysis and they found that the optimal multi-objective parametric settings (which correspond to the highest grey relational grade of all experimental runs) were $1.5 \mathrm{~A} / 5 \mu \mathrm{s} / 0.5 \mathrm{~kg} / \mathrm{cm}^{2}$. In the same work, they carried out a comparative study of micro hole machining of $\mathrm{Ti}_{6} \mathrm{Al}_{4} \mathrm{~V}$ alloy using kerosene and de-ionized water. They found that MRR and EWR were high comparatively using de-ionized water than kerosene; using kerosene taper and overcut were low. In spite of some parametric settings, the values of taper and overcut were low using de-ionized water.

Azad and Puri (2012) followed the technique developed by Antony (Antony, 2001) in order to optimize simultaneously the quality characteristics MRR, overcut and EWR, having as process factors voltage, current, frequency and pulse width. They calculated the loss function, which measures the deviations of the experimental values from the mean, for each normalized performance characteristic. The loss functions were transformed into $\mathrm{S} / \mathrm{N}$ ratio based in Taguchi's philosophy. A weighted method was used to illustrate the relative importance of quality characteristics by assigning the greatest importance to the MRR and the overcut, and less importance to EWR. The final total loss function is transformed into S/N ratios and the simultaneous optimal settings are defined. They relied on the magnitude of $\mathrm{F}$ in ANOVA in order to conclude that the most influential factors were the frequency and pulse on time (in contrast to other results). The use of $\mathrm{F}$ for determining importance is not illegitimate since they used an orthogonal array design, but the weighted method, especially with the MRR and OC assumed more important and EWR less important is questionable.

Meena and Azad (2012) in this most cited paper, after choosing as control factors Voltage (V) $\{80,150\}$, Frequency (KHz) $\{150,200,250\}$, Current (index value) $\{20,50,80\}$, Pulse on time $(\mu \mathrm{s})\{0.5,1,2\}$, and L9 orthogonal array and as quality parameters MRR, EWR and Overcut determine the optimal settings for the performance characteristics at $80 \mathrm{~V} / 200 \mathrm{KHz} /$ $20 / 0.5 \mu \mathrm{s}$. By using the mean of grey relational grades of all parameters at different levels of all control factors and the difference between the maximum and the minimum value of the grey relational grades, the authors concluded that in micro-EDM drilling of $\mathrm{Ti}_{6} \mathrm{Al}_{4} \mathrm{~V}$ alloy the most important parameters are, in the order, voltage (lower level), current (middle level), pulse width (higher level) and frequency (lower level).

Lin et al.(2015) combined Grey Relational analysis and Taguchi methods to optimize the input parameters Peak Current(A) $\{0.3,0.5,1\}$, Pulse on time( $\mu$ s) $\{6,13,25\}$, Pulse off time $(\mu \mathrm{s})\{3,6,13\}$, and gap Voltage (V) $\{30,35$, $40\}$,based on L9 design of experiment. They wanted to demonstrate that the use of the Grey-Taguchi method results in clear improvements in quality characteristics related to the single use of Taguchi method. First, by conducting ANOVA for the $\mathrm{S} / \mathrm{N}$ rations of the multiple performance characteristics, with treatments the three levels of the micro-EDM process factors they determined three optimal sets of the control factors: for lower Electrode Depletion : $0.3 \mathrm{~A} / 6 \mu \mathrm{s} / 13 \mu \mathrm{s} / 40 \mathrm{~V}$, for higher MRR : $0.5 \mathrm{~A} / 6 \mu \mathrm{s} / 13 \mu \mathrm{s} / 40 \mathrm{~V}$ and lower overcut : $0.3 \mathrm{~A} / 6 \mu \mathrm{s} / 6 \mu \mathrm{s} / 40 \mathrm{~V}$. Then, they computed the grey relational grades. They transformed the grey relational grades into $\mathrm{S} / \mathrm{N}$ ratios (again) and the ANOVA of these new relational grades proved that the main contribution to the multiple performance characteristics for the micro-EDM of $\mathrm{Ti}_{6} \mathrm{Al}_{4} \mathrm{~V}$ alloy came from peak current at $67.52 \%$ and pulse on time at $28.65 \%$. By reading the $\mathrm{S} / \mathrm{N}$ graph of the grey 
relational grades, they concluded that the optimal settings for the best multiple performance characteristics for micro-EDM of $\mathrm{Ti}_{6} \mathrm{Al}_{4} \mathrm{~V}$ were $0.3 \mathrm{~A} / 6 \mu \mathrm{s} / 13 \mu \mathrm{s} / 40 \mathrm{~V}$. By a confirmation experiment, they found that the Electrode Depletion is decreased from 129.1 to $70.6 \mu \mathrm{m}$, MRR is decreased from 8.58 to $4.05 \times 10^{-4} \mathrm{~mm}^{3} / \mathrm{min}$ and the overcut is decreased from 20.00 to $16.23 \mu \mathrm{m}$. Also, the pulse off time and the voltage gap proved insignificant factors.

Huang et al. (2018) used as control factor Pulse duration ( $\mu$ s) $\{1,2,3\}$, Pulse off time ( $\mu$ s) $\{1,2,3\}$, Discharge Current (A) $\{0.5,1,1.5\}$ and Working Period (s) $\{1,2,3\}$ and an L9 orthogonal table for the Taguchi quality design. The Taguchi method determined that: the pulse off time (41.33\%) and discharge current (38.44\%) have a great effect on EWR; the discharge current and working period are the most significant factors for MRR with approximate contribution ( 63.99\% and $20.71 \%$ respectively); the pulse off time $(40.5 \%)$ and the pulse duration (37\%) have the most significant effect on overcut. By Taguchi method got some multi-objective optimal settings. On the other hand, they applied grey relational analysis to the original data, and determined the optimum level for the process parameters (which is the level with the highest grey relational grade): $1 \mu \mathrm{s} / 3 \mu \mathrm{s} / 1.5 \mathrm{~A} / 3 \mathrm{~s}$. Next, they calculated the $\mathrm{S} / \mathrm{N}$ ratios of the grey relational grade for each experiment in L9 orthogonal array and conducted ANOVA for the new S/N ratios. They got a better approximation for the optimal parametric settings: $2 \mu \mathrm{s} / 3 \mu \mathrm{s} / 1.5 \mathrm{~A} / 3 \mathrm{~s}$ which resulted in $12.26 \%$ improvement in MRR, $1.35 \%$ in EWR, and $4.34 \%$ in overcut. The ANOVA for the grey relational grades proved that the most insignificant factors for micro-EDM milling of $\mathrm{Ti}_{6} \mathrm{Al}_{4} \mathrm{~V}$ were pulse off time $43.31 \%$ and current discharge $31.25 \%$.

Belloti et al. (2018) decided to choose a large number of machining factors: Pulse width ( $\mu$ s), Frequency kHz, Current (index), Open Voltage (V), Reference Discharge Voltage(V) and Gain, all at 2 levels, and they based their design of experiment on an L32 orthogonal array. They found that the most relevant factor influencing both MRR and TWR was the open voltage. Open voltage and pulse width had the most relevant effects on surface roughness. The optimal settings for the responses MRR, EWR and surface roughness were obtained at lower level pulse width, higher level frequency and lower level current, open voltage, discharge voltage and gain: $4 \mu \mathrm{s} / 160 \mathrm{kHz} / 90 / 120 \mathrm{~V} / 40 \mathrm{~V} / 24$

In some other works (Aravind et al., 2017), researchers tried to apply Taguchi method for discovering the optimal micro-EDM process parameters, but they do not analyze exhaustively because we do not have enough information about the planning of the experiment or the calculations of the ratios. In other papers, the optimal set of parameters is not found (Mohanti et al. 2108).

\section{Future Research Questions and Suggestions for Teaching Purposes}

By inspecting all the above-mentioned studies, we conclude that the results found were not in accordance across different methods, particularly related to the levels of voltage and peak current; this can be due to the different sets of independent variables. The most studied response variables were the MRR and EWR, while overcut or surface roughness were less studied.

Almost in all the studies, the authors used the same process parameters. However, some parameters have not yet been thoroughly investigated, like electrode diameter which has been reported as a parameter that has statistically significant influence on the performance parameters of the micro-EDM process machining (D'Urso \& Ravacio, 2016). Additionally, the experiments were conducted with electrodes of $0.3 \mathrm{~mm}$ to $0.5 \mathrm{~mm}$ diameters. A smaller electrode diameter could reveal some new results.

We have provided the reader with a considerably large set of experiments each of which consists of at least 10 settings of independent variables and measurements of associated response variables; in each experiment, one of the main optimization techniques was used for determining the most influential factors on the behavior of response variables or finding optimum sets of variables. Very often, for each experimental trial, the authors offer some physical explanations for the relations between micro-EDM process parameters and response variables. Thus, the micro-EDM mechanical process offers a link of facts and theories across disciplines (engineering, optimization methods and physics), and creates a multifaceted topic to be studied, perhaps at the same time in case of multidisciplinary teaching. In any case, the database can be used as a concrete example of application of various optimization techniques, of advantages of one technique over the other and of a physical explanation of the electrothermal principles that govern the micro-EDM machining process.

\section{Conclusion}

In this study, we tried to describe how researchers optimized the machining factors in micro-EDM machining process of $\mathrm{Ti}_{6} \mathrm{Al}_{4} \mathrm{~V}$ alloy over the last two decades. Many of the well- known optimization techniques were used. Often findings were in accordance with each other, but also great dissimilarities were observed even in essential questions, like the increase of the MRR or the decrease of the EWR. A further consistent research must be conducted aiming to reveal the most significant factors in specific experimental conditions as well as the factors that caused the dissimilarities. This study, we believe, also has a considerable educational impact since the abundant number of the real-world data that can be found in the tables and references offer concrete examples for practicing various statistical techniques, comparing results and 
finding discrepancies.

\section{Reference}

Alavi, F., \& Jahan, M. P. (2017). Optimization of process parameters in micro-EDM of Ti-6Al-4V based on full factorial design. International Journal of Advanced Manufacturing Technology, 92(1-4), 167-187. https://doi.org/10.1007/s00170-017-0103-x

Ali, M. Y., Adesta, E. Y. T., Rahman, N. A. B. A., \& Aris, E. B. M. (2012). Powder Mixed Micro Electro Discharge Milling of Titanium Alloy: Analysis of Surface Roughness. Advanced Materials Research, Transactions Technology Publications, $\quad 341-342, \quad 142-146, \quad$ Switzerland. https://doi.org/10.4028/www.scientific.net/AMR.341-342.142

Antony, J. (2001). Simultaneous Optimization of Multiple Quality Characteristics in Manufacturing Processes Using Taguchi’s Quality Loss Function. International Journal Advances in Manufacturing Technology, 17, 134-138. https://doi.org/10.1007/s001700170201

Aravind, R., Ganesh, S., Yasir, S. M., Madhan-Mohan, G., Krishnarah, V., \& Parthiban, M. (2015). Experimental Investigation and Parameter Optimization of Micro Holes Machining on Ti-6Al-4V Alloy. Applied Mechanics and Materials, 813-814, 332-336. https://doi.org/10.4028/www.scientific.net/AMM.813-814.332

Azad, M. C., \& Puri, A. B. (2012). Simultaneous optimization of multiple performance characteristics in micro-EDM drilling of titanium alloy. International Journal of Advanced Manufacturing Technology, 61(9-12), 1231-1239. https://doi.org/10.1007/s00170-012-4099-y

Badampudi, D., Wohlin, C., \& Petersen, K. (2015). Experiences from using snowballing and database searches in systematic literature revues. Proceedings of the $19^{\text {th }}$ International Conference on Evaluation and Assessments in Software Engineering, Article No 17, Nanjing, China. https://doi.org/10.1145/2745802.2745818

Barman, S., Puri, A. B., \& Nagahanumaiah. (2017). Analysis of Surface Texture of High Aspect Ratio Blind Micro Holes on Titanium Alloy (Ti-6Al-4V) in Micro Electrical Discharge Drilling. Solid State Phenomena Transactions Technology Publications, 261, 151-158, Switzerland. https://doi.org/10.4028/www.scientific.net/SSP.261.151

Belloti, M., Qian, J., \& Reynaerts, D. (2018). Enhancement of the micro-EDM process for drilling through-holes. Procedia CIRP, 68, 610-615. https://doi.org/10.1016/j.procir.2017.12.123

Chow, H. M., Yan, B. H., Huang, F. Y., \& Hung, G. C. (2000). Study of added powder in kerosene for the micro-slit machining of titanium alloy using electro-discharge machining. Journal of Materials Processing Technology, 101(1-3), 95-103. https://doi.org/10.1016/S0924-0136(99)00458-6

Chow, H. M., Yang, L. D., Lin, C. T., \& Chen, W. F. (2008). The use of SiC powder in water as dielectric for micro-slit EDM machining. Journal of Materials Processing Technology, 195(1-3), 160-179. https://doi.org/10.1016/j.jmatprotec.2007.04.130

D’Urso, G., \& Ravasio, C. (2016). The effects of electrode size and discharged power on micro-electro-discharge machining drilling of stainless steel. Advances in Mechanical Engineering, 8(5), 1-12. https://doi.org/10.1177/1687814016648646

Ezugwu, E. O., \& Wang, Z. M. (2001). Titanium alloys and their machinability-a review. Journal of Materials Processing Technology, 68(3), 262-274. https://doi.org/10.1016/S0924-0136(96)00030-1

Huang, G. C., Yang, A. B., \& Hsu, C. H. (2018). The optimization of micro EDM milling of Ti-6Al-4V using a grey Taguchi method and its improvement by electrode coating. International Journal of Advanced Manufacturing Technology, 96, 3851-3859. https://doi.org/10.1007/s00170-018-1841-0

Jithin, S., Kuriachen, B., \& Mathew, J. (2013). Modelling of $\mu$-ED Milling of Ti-6Al-4V using RSM and ANN. International Conference on Precision Micro-Meso and Nano Engineering, COPEN-8. https://doi.org/10.1504/IJPTECH.2014.067745

Kibria, G., \& Pradhan, P. P. (2012). Multi-Criteria Optimization of Electro-Discharge Micro-Hole Machining of Ti-6al-4v Super Alloy. Journal of Machining and Forming Technologies, 4(3/4), 159-186.

Kibria, G., Pradhan, B. B., \& Bhattacharyya, B. (2012). Experimentation and Analysis into Micro-Hole Machining in EDM onTi-6al-4v Alloy Using Boron Carbide Powder Mixed De-Ionized Water. International Journal of Mechanics and Materials in Design, 1(1), 17-35. https://doi.org/10.4018/ijmmme.2014010102

Kibria, G., Sarkar, P. B. B., \& Bhattacharyya, B. (2010). Comparative study of different dielectrics for micro-EDM performance during microhole machining of Ti-6Al-4V alloy. International Journal of Advance Manufacturing 
Technology, 48, 557-570. https://doi.org/10.1007/s00170-009-2298-y

Kitchenham, B., Brereton, P., Budgen, D., Turner, M., Bailey J., Linkman, S. (2009). Systematic literature reviews in software engineering-A systematic literature review, Journal of Information and Software Technology, 51, 7-15. https://doi.org/10.1016/j.infsof.2008.09.009

Krishnaraj, V. (2016). Optimization of Process Parameters in Micro-EDM of Ti-6Al-4V Alloy. Journal for Manufacturing Science and Production, 16(1), 41-49. https://doi.org/10.1515/jmsp-2015-0024

Kumar, R., \& Singh, I. (2018). Productivity improvement of micro EDM process by improvised tool. Precision Engineering, 51, 529-235. https://doi.org/10.1016/j.precisioneng.2017.10.008

Kuriachen, B., \& Mathew, J. (2014). Modeling of material removal mechanism in Micro Electrical Discharge Milling of Ti-6Al-4V. Applied Mechanics and Materials, Transactions Technology Publications, 594-594, 516-520, Switzerland. https://doi.org/10.4028/www.scientific.net/AMM.592-594.516

Kuriachen, B., \& Mathew, J. (2015). Experimental Investigations into the Effects of Microelectric-Discharge Milling Process Parameters on Processing Ti-6Al-4V. Materials and Manufacturing Processes, 30(8), 983-990. https://doi.org/10.1080/10426914.2014.984206

Kuriachen, B., \& Mathew, J. (2016a). Effect of Powder Mixed Dielectric on Material Removal and Surface Modification in Microelectric Discharge Machining of Ti-6Al-4V. Materials and Manufacturing Processes, 31(4), 439-446. https://doi.org/10.1080/10426914.2015.1004705

Kuriachen, B., \& Mathew, J. (2016b). Spark radius modeling of resistance-capacitance pulse discharge in micro-electric discharge machining of Ti-6Al-4V: an experimental study. International Journal of Advanced Manufacturing Technology, 85(9-12), 1983-1993. https://doi.org/10.1007/s00170-015-7999-9

Kuriachen, B., Somashekhar, K. P., \& Mathew, J. (2014). Multiresponse optimization of micro-wire electrical discharge machining process. International Journal of Advanced Manufacturing Technology, 76(1-4), 91-104. https://doi.org/10.1007/s00170-014-6005-2

Lin, M. Y., Chao, C. C., Huang, H. H., Wu, C. Y., \& Hsu, C. Y. (2015). Use of the grey-Taguchi method to optimize the micro-electrical discharge machining (micro-EDM) of Ti-6Al-4V alloy. International Journal of Computer Integrated Manufacturing, 28(6), 569-576. https://doi.org/10.1080/0951192X.2014.880946

Masuzawam, T. (2001). Micro-EDM. Proceedings of the 13th International Symposium for Electromachining, 3-19.

Meena, V. K., \& Azad, M. S. (2012). Grey Relational Analysis of Micro-EDM Machining of Ti-6Al-4V Alloy. Material and Manufacturing Processes, 27(9), 973-979. https://doi.org/10.1080/10426914.2011.610080

Mohanti, S., Kumar, V., Tyagi, R., Kumar, S., Bhushan, B., Das, A. K., \& Dixit, A. R. (2018). Surface alloying using tungsten disulphide powder mixed in dielectric in micro-EDM on Ti6Al4V. IOP Conf. Ser.: Mater. Sci. Eng., 377 012040. https://doi.org/10.1088/1757-899X/377/1/012040

Parveen, A., \& Jahan, M. P. (2018). Modeling and optimization of crater size generated during micro- EDM of Ti alloy using Response surface method. Materials Today Proceedings, 5(9-3), 18307-18314. https://doi.org/10.1016/j.matpr.2018.06.169

Parveen, A., Jahan, M. P., \& Zhugagulova, S. (2018). Statistical Modeling and Optimization of Micro Electro Discharge Machining of $\mathrm{Ti}$ Alloy. Materials Today Proceedings, 5(2-1), 4803-4810. https://doi.org/10.1016/j.matpr.2017.12.054

Phipon, R., \& Pradhan, B. B. (2012). Process Parameters Optimization of Micro Electric Discharge Machining Process Using Genetic Algorithm. International Journal of Engineering Research Applications, 2(5), 1986-1993.

Plaza, S., Sanchez, J. A., Perez, E., Gil, R., Izquierdo, B., Ortega, N., \& Pombo, I. (2014). Experimental study on micro EDM-drilling of Ti6Al4V using helical electrode. Precise Engineering, 38(4), 821-827. https://doi.org/10.1016/j.precisioneng.2014.04.010

Pradhan, B. B., \& Bhattacharyya, B. (2008). Improvement in microhole machining accuracy by polarity changing technique for microelectrode discharge machining on Ti--6Al--4V. Proceedings of the Institution of Mechanical Engineers Part B, Journal of Engineering Manufacturing, 222, 163-173. https://doi.org/10.1243/09544054JEM959

Pradhan, B. B., \& Bhattacharyya, B. (2009). Modelling of micro-electro discharge machining during machining of titanium alloy $\mathrm{Ti}-6 \mathrm{Al}-4 \mathrm{~V}$ using response surface methodology and artificial neural network algorithm. Proceedings of the Institution of Mechanical Engineers Part B, Journal of Engineering Manufacturing, 223, 683-693. 
Pradhan, B. B., Masanta, M., Sarkar, B. R., \& Bhattacharyya, B. (2009). Investigation of electro-discharge micro-machining of titanium super alloy. International Journal of Advanced Manufacturing Technology, 41, 1094-1106. https://doi.org/10.1007/s00170-008-1561-y

Sapkal, S. U., \& Jagtap, P. S. (2018). Optimization of Micro EDM Drilling Process Parameters for Titanium Alloy by Rotating Electrode. 2nd International Conference on Materials Manufacturing and Design Engineering, Procedia Manufacturing, 20, 119-126. https://doi.org/10.1016/j.promfg.2018.02.017

Singh, P., Yadava, V., \& Narayan, A. (2018). Parametric study of ultrasonic-assisted hole sinking micro-EDM of titanium alloy. International Journal of Advanced Manufacturing Technology, 94(5-8), 2551-2562. https://doi.org/10.1007/s00170-017-1051-1

Sivaprakasam, P., Hariharan, P., \& Gowri, S. (2014a). Analysis of Machining Parameters of $\mu$-WEDM on Titanium Alloy, International Journal of Applied Engineering Research, 9(26), 8893-8896.

Sivaprakasam, P., Hariharan, P., \& Gowri, S. (2014b). Modeling and analysis of micro-WEDM process of titanium alloy (Ti-6Al-4V) using response surface approach. Engineering Science and Technology an International Journal, 17(4), 227-235. https://doi.org/10.1016/j.jestch.2014.06.004

Tiwary, A. P., Pradhan, B. B., \& Bhattacharyya, B. (2013). Parametric Optimization of Micro-EDM Process Using Response Surface Methodology and Principal Component Analysis. Journal of Manufacturing Technology Research, 5(3/4), 117-136.

Tiwary, A. P., Pradhan, B. B., \& Bhattacharyya, B. (2014a). Study on the influence of micro-EDM process parameters during machining of Ti-6Al-4V superalloy. International Journal of Advanced Manufacturing Technology, 760(1), 151-160. https://doi.org/10.1007/s00170-013-5557-x

Tiwary, A. P., Pradhan, B. B., \& Bhattacharyya, B. (2018). Parametric Optimization of Micro-EDM Process during Micro-hole Machining on Ti-6Al-4V using WASPAS Method. International Conference on Mechanical, Materials and Renewable Energy IOP Conf. Ser:: Mater. Sci. Eng., 377. https://doi.org/10.1088/1757-899X/377/1/012202

Tiwary, A. P., Pradhan, B. P., \& Bhattacharyya, B. (2014b). Application of multi-criteria decision-making methods for selection of micro-EDM process parameters. Advances in Manufacturing, 2(3), 251-258. https://doi.org/10.1007/s40436-013-0050-1

Tiwary, A. P., Pradhan, B. P., \& Bhattacharyya, B. (2014c). Investigation on the effect of dielectrics during micro-electro-discharge machining of Ti-6Al-4V. International Journal of Advanced Manufacturing Technology, 95, 861-874. https://doi.org/10.1007/s00170-017-1231-z

Wang, K., Zhang, Q., Liu, Q., \& Huang, Y. (2017). Experimental study on micro-electrical discharge machining with helical electrode. International Journal of Advanced Manufacturing Technology, 93, 2639-2645. https://doi.org/10.1007/s00170-017-0747-6

Weule, H., Fleischer, J., Bookhholz, C., Knoll, M., Elsner, J., \& Tritschler, H., et al. (2004). Inter-national state of the art of micro production technology. Production Engineering-Research and Development, XI, 29-36.

\section{Copyrights}

Copyright for this article is retained by the author(s), with first publication rights granted to the journal.

This is an open-access article distributed under the terms and conditions of the Creative Commons Attribution license (http://creativecommons.org/licenses/by/4.0/). 